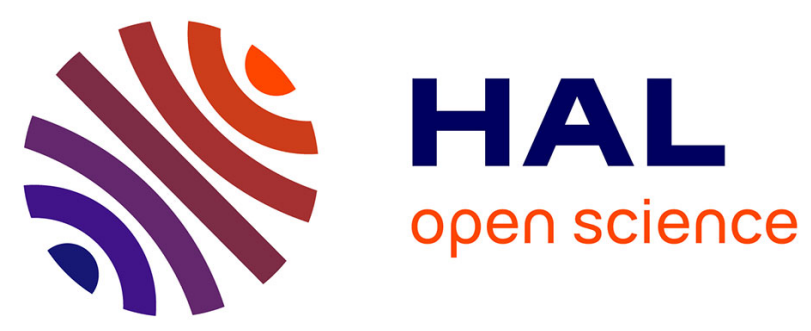

\title{
Geochemical investigation of a sediment core from the Trajan basin at Portus, the harbor of ancient Rome
} H Delile, I Mazzini, Janne Blichert-Toft, Jean-Philippe Goiran, F Arnaud-Godet, F Salomon, F Albarède

\section{- To cite this version:}

H Delile, I Mazzini, Janne Blichert-Toft, Jean-Philippe Goiran, F Arnaud-Godet, et al.. Geochemical investigation of a sediment core from the Trajan basin at Portus, the harbor of ancient Rome. Quaternary Science Reviews, 2014, 87, pp.34 - 45. 10.1016/j.quascirev.2014.01.002 . halshs-01099838

\section{HAL Id: halshs-01099838 \\ https://shs.hal.science/halshs-01099838}

Submitted on 7 Jan 2015

HAL is a multi-disciplinary open access archive for the deposit and dissemination of scientific research documents, whether they are published or not. The documents may come from teaching and research institutions in France or abroad, or from public or private research centers.
L'archive ouverte pluridisciplinaire HAL, est destinée au dépôt et à la diffusion de documents scientifiques de niveau recherche, publiés ou non, émanant des établissements d'enseignement et de recherche français ou étrangers, des laboratoires publics ou privés. 
Provided for non-commercial research and education use. Not for reproduction, distribution or commercial use.

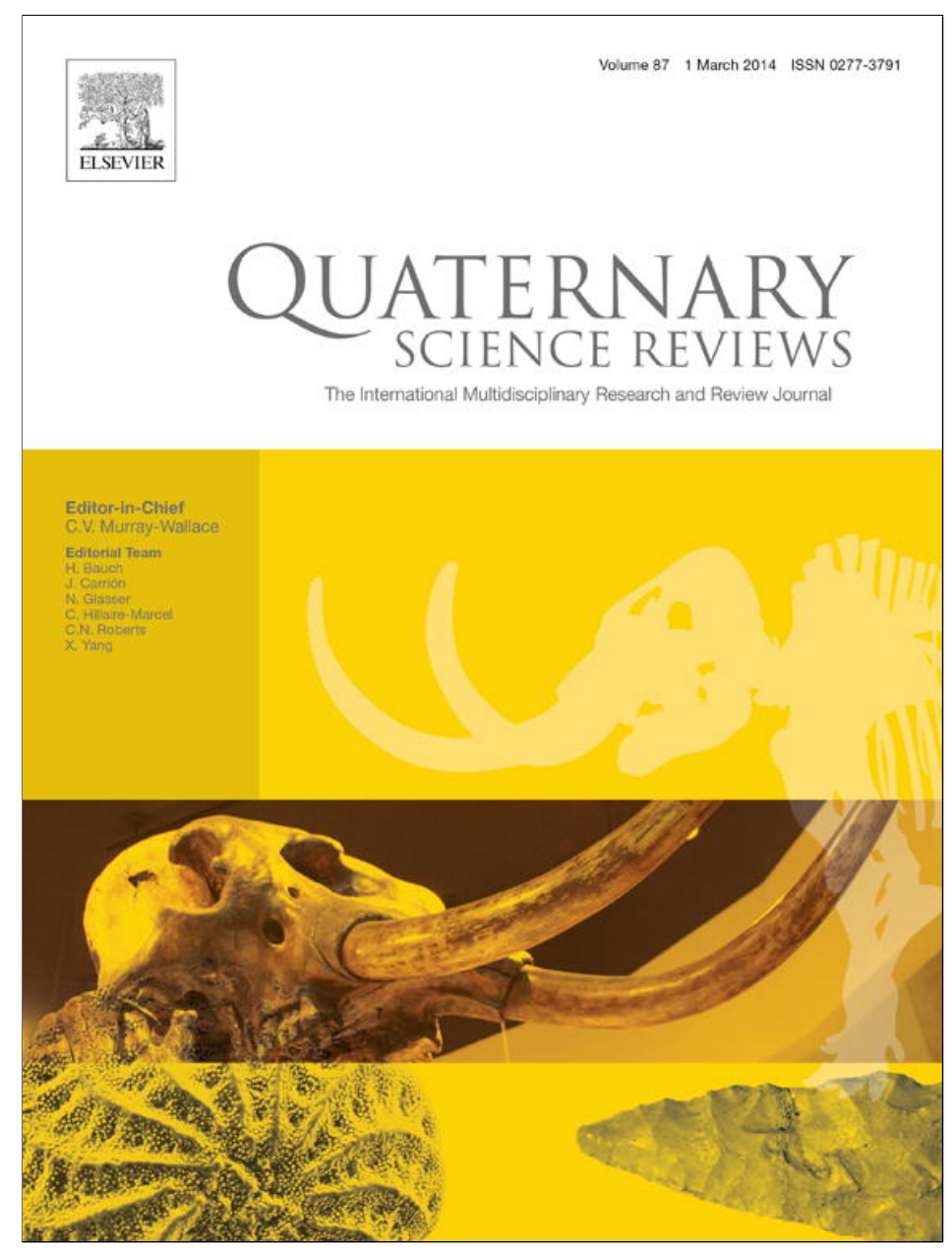

This article appeared in a journal published by Elsevier. The attached copy is furnished to the author for internal non-commercial research and education use, including for instruction at the authors institution and sharing with colleagues.

Other uses, including reproduction and distribution, or selling or licensing copies, or posting to personal, institutional or third party websites are prohibited.

In most cases authors are permitted to post their version of the article (e.g. in Word or Tex form) to their personal website or institutional repository. Authors requiring further information regarding Elsevier's archiving and manuscript policies are encouraged to visit:

http://www.elsevier.com/authorsrights 


\title{
Geochemical investigation of a sediment core from the Trajan basin at Portus, the harbor of ancient Rome
}

\author{
H. Delile ${ }^{\mathrm{a}, \mathrm{c}, *}$, I. Mazzini ${ }^{\mathrm{b}}$, J. Blichert-Toft ${ }^{\mathrm{c}, \mathrm{d}}$, J.P. Goiran ${ }^{\mathrm{e}}$, F. Arnaud-Godet ${ }^{\mathrm{c}}$, F. Salomon ${ }^{\mathrm{a}, \mathrm{f}}$, \\ F. Albarède ${ }^{\mathrm{c}, \mathrm{d}}$ \\ ${ }^{a}$ Université Lumière Lyon 2, CNRS UMR 5600, 69676 Bron, France \\ ${ }^{\mathrm{b}}$ Dipartimento di Scienze, Università di Roma 3, Viale Marconi 466, 00146 Rome, Italy \\ ${ }^{\mathrm{c}}$ Ecole Normale Supérieure de Lyon, Université Claude Bernard-Lyon I, CNRS UMR 5276, 69007 Lyon, France \\ ${ }^{\mathrm{d}}$ Department of Earth Science, Rice University, Houston, TX 77005, USA \\ e Maison de l'Orient et de la Méditerranée, CNRS UMR 5133, 69365 Lyon Cedex 7, France \\ ${ }^{\mathrm{f}}$ University of Southampton, School of Humanities, Archaeology, Avenue Campus, Southampton SO 171 BF, Great Britain, UK
}

\section{A R T I C L E I N F O}

\section{Article history:}

Received 18 December 2013

Accepted 2 January 2014

Available online 24 January 2014

\section{Keywords:}

Geoarcheology

Geochemistry

Ostracods

Sedimentology

Tiber delta

Roman harbor

Late Holocene

\begin{abstract}
A B S T R A C T
From the 1st century $\mathrm{AD}$ and for the duration of the Roman Empire, the Portus complex was the main harbor of Rome. Its location on the Tiber delta next to the Tyrrhenian Sea produced rapid environmental changes that, together with historical vicissitudes, largely determined the fate of the harbor. We have assembled data on the mineralogy, sedimentology, geochemistry, and ostracod populations of a sediment core drilled in the access channel of the hexagonal basin of Trajan, with the expectation that such a combined data set will shed new light on how the connections of the inland Trajan basin with the Tiber river, the earlier Claudius harbor on the nearby shoreline, and the sea evolved through the centuries. The data define four distinct periods which geochemistry characterizes by different conditions of salinity and oxygenation. These in turn can be related to historical periods and events by means of ${ }^{14} \mathrm{C}$ data. The early Imperial Period was dominated by input of well-oxygenated freshwater from the Tiber. During the Late Empire, harbor water became relatively more influenced by seawater and increasingly oxygen deficient, which attests to a decommissioning of the Canale Trasverso connecting the harbor to the Tiber. The strong anthropogenic signal, which is visible very clearly in geochemical parameters, attests to the human occupation of the harbor area up to the Early Middle Ages, when human activity was brought to an abrupt end. The simultaneous use in this study of multiple complementary tracers has allowed for the sedimentary sources of the different classes of particles in the harbor basin to be identified and assigned to either the freshwater supply from the Canale Trasverso or the seawater of the Claudius harbor.
\end{abstract}

(c) 2014 Elsevier Ltd. All rights reserved.

\section{Introduction}

Portus was a maritime harbor established on the right bank of the Tiber by emperors Claudius (41-54 AD) and Trajan (98-117 AD) to reinforce the supply of commodities to Rome that could not adequately be handled by Ostia. Food shortages had recently stricken Rome (Suétone, 1993), the population of which reached a million inhabitants in the Imperial Period. In addition, after a succession of major floods of the Tiber dating from the 2 nd c. BC to the first quarter of the 1 st c. AD, definitive silting-in impaired the river harbor of Ostia (Goiran et al., 2014). The Claudius harbor was a system of peers and

\footnotetext{
* Corresponding author. Université Lumière Lyon 2, CNRS UMR 5600, Avenue Pierre Mendès-France, 69676 Bron, Cedex 00, France. Tel.: +33 (0)6 82736653. E-mail address: hdelile@gmail.com (H. Delile).
}

jetties constructed on the shoreline but which quickly turned out to be inadequate to protect ships efficiently against storms. This prompted the digging by Trajan of an additional inland hexagonal basin surrounded by storehouses and official buildings. Silting of the Tiber delta was probably also the main reason why the emperor Claudius had an artificial channel constructed, called the Fossa Traiana, the present-day Fiumicino channel, linking the harbor to the Tiber, in order to reduce the vulnerability of the Roman capital to the risk of flooding (Mazzini et al., 2011). A few years later, the creation of the Canale Trasverso enabled connection of the Fossa Traiana with the access channel of the Trajan basin and thus constituted the only waterway between the harbor basins and the river (Keay et al., 2005).

The pattern of waterways and the fluvial regime of Portus, and, with these, some critical aspects of harbor traffic, remain poorly understood (Salomon et al., 2010, in press; Pepe et al., 2013; submitted). The motivation of the present work is to combine evidence 
from sedimentology, ostracology, and geochemistry to address these issues. We also focus on how the waterways evolved historically in the context of an advancing shoreline and constant remodeling of the coastal environment (Giraudi, 2011). In the harbor surroundings, sediments combine the record of human impact and natural processes (Goiran and Morhange, 2003; Marriner et al., 2010). The recent reconstruction of the paleoenvironmental evolution of the harbor complex of Rome has attracted much attention (Arnoldus-Huyzendveld, 2005; Giraudi et al., 2007; Goiran et al., 2007, 2008; Bellotti et al., 2009; Giraudi et al., 2009; Goiran et al., 2010; Mazzini et al., 2011) and has, in particular, contributed to the understanding of the role of such harbors as maritime gateways.

In the present work, we focus on the interaction between fluvial and marine influences in the deposits of the harbor basin of Trajan. Questions such as the sedimentary contribution from the Claudius harbor, the role it played in the sealing off of the Trajan basin, and the possibility that sandy sediments were injected into the latter during floods of the Tiber Canale Trasverso (Fig. 1) (Salomon et al., 2012) will be addressed.

While geoarcheological investigative methods in harbor environments principally rest on micropaleontology (molluscs, ostracods, foraminifera, diatoms, pollen) and sedimentology (texture, granulometry, exoscopy) (Goiran and Morhange, 2003; Marriner and Morhange, 2007; Cubizolle, 2009), geochemistry has emerged only recently as an additional source of information useful to the identification of anthropogenic components (pollution) (Goiran, 2001; Le Roux et al., 2003; Le Roux et al., 2005; Véron et al., 2006; Delile et al., 2012; Elmaleh et al., 2012). A ca $9 \mathrm{~m}$ deep sediment core, hereafter referred to as TR14, was drilled in the access channel of the Trajan basin at the zone of convergence between the fluvial influences coming from the Canale Trasverso and seawater coming from the Claudius harbor, which is open to the sea (Fig. 1). We sampled the core in detail and analyzed it for grain-size distributions (42 samples), ostracod populations (36 samples), and major and trace element concentrations (42 samples). We also analyzed 10 samples for ${ }^{14} \mathrm{C}$ ages. In order to strengthen the age model in the upper part of TR14, we further drew on ages obtained on the nearby core CT1 by Salomon et al. (2012) and analyzed the major and trace element concentrations in and around a remarkable carbonate-rich level. Based on these results, we make inferences about the hydrological and sedimentary processes in this sector of the Trajan basin and discuss the origin of fine and coarse particles in the Trajan harbor as a whole.

\section{Study area}

The Tiber delta is the outlet for the discharge of a $405 \mathrm{~km}$ long river that drains the waters of a basin sloping NW-SE with a surface area of $17,375 \mathrm{~km}^{2}$. The basement of the Tiber watershed comprises young sediments of the Apennines and modern volcanic deposits in Latium. The annual sedimentary contributions to the Tyrrhenian Sea, estimated at 7.2 million tons per year (Iadanza and Napolitani, 2006), have resulted in the construction, since the last glaciation, of a delta dominated by swells. The Tiber delta can be divided into two zones: (i) the inner zone, in the east, relating to the ancient lagoons of Maccarese in the north and Ostia in the south (Bellotti et al., 2007), and (ii) the outer zone, in the west, where the landscape is composed of accreting bars of dunes. For information about the maritime context (wind rose, swell rose, long drift current, bathymetry, storminess, waves heights...) the reader is referred to Noli et al. (1996). The present Tiber delta is the result of a

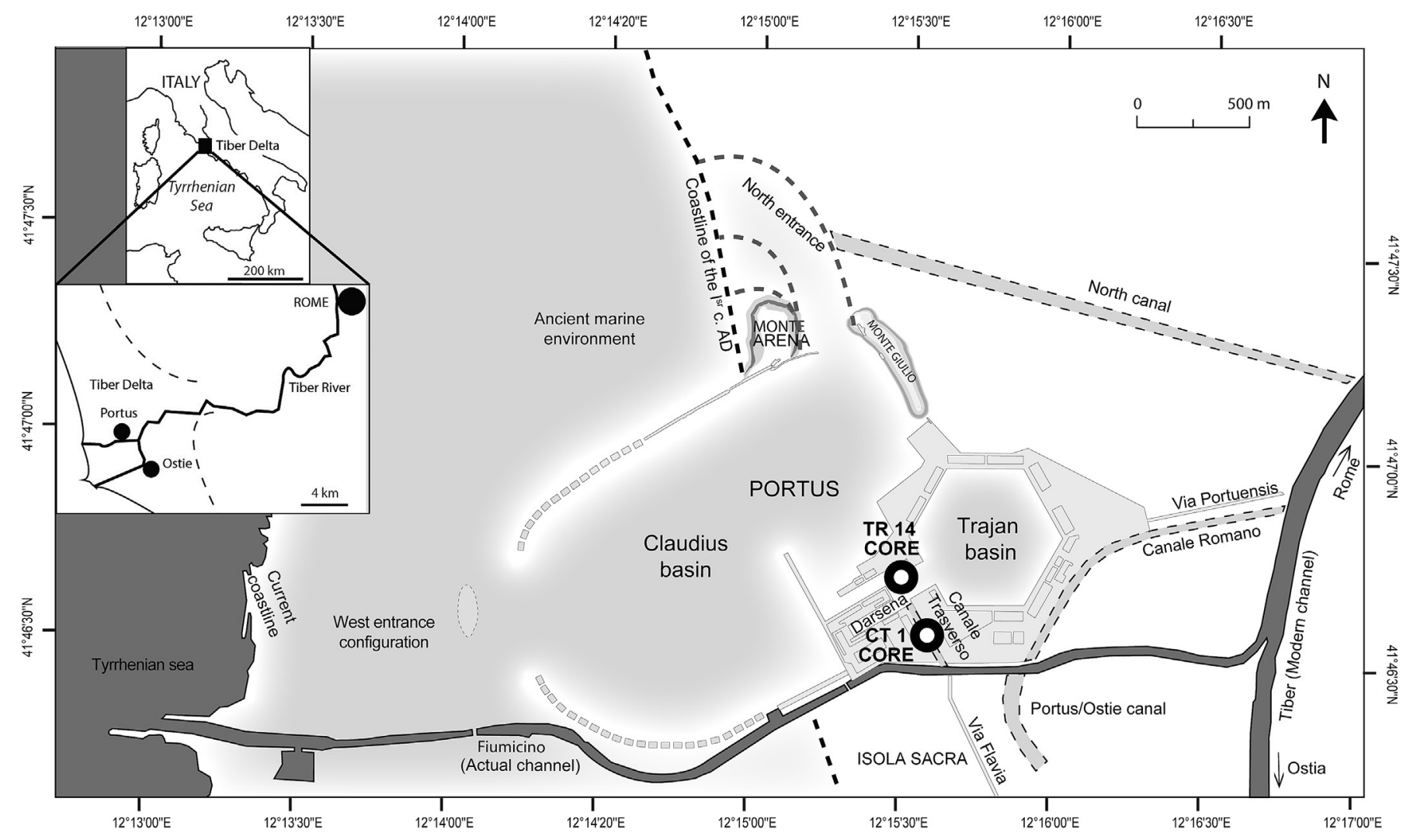

Fig. 1. Map of the Portus area with the Claudius and Trajan harbors and connecting waterways showing the location of core TR14 analyzed in this work and of core CT1 analyzed by Salomon et al. (2012). For a detailed description of the various infrastructures and buildings, and a discussion of their ages, the reader is referred to Keay et al. (2005) and Keay and Paroli (2011). 
Table 1

${ }^{14} \mathrm{C}$ dating of the cores TR14 and CT1. Ages were calibrated according to the IntCal09 and Marine09 (marked by an asterix) radiocarbon calibration curves (Reimer et al., 2009).

\begin{tabular}{|c|c|c|c|c|c|c|c|}
\hline Core & Depth $(\mathrm{cm})$ & Laboratory code & Code & Material & $\delta^{13} \mathrm{C}$ & ${ }^{14} \mathrm{C}$ age (BP) & Calendar age $(\mathrm{BC}-\mathrm{AD})(2 \sigma)$ \\
\hline TR 14 & $341-344$ & Lyon-7474 & $\mathrm{d} 8 \mathrm{~b}$ & Vegetal matter* & -13.26 & $2160 \pm 30$ & $97-284 \mathrm{AD}$ \\
\hline TR 14 & $341-344$ & Lyon-8067 & d8a & Posidonia* & -13.85 & $2165 \pm 25$ & $104-266 \mathrm{AD}$ \\
\hline TR 14 & $403-406$ & Lyon-8068 & d7 & Posidonia* & -13.35 & $2145 \pm 25$ & $130-305 \mathrm{AD}$ \\
\hline TR 14 & $432-435$ & Lyon-8069 & d6 & Posidonia* & -13.86 & $2035 \pm 25$ & $265-426 \mathrm{AD}$ \\
\hline TR 14 & $549-549.5$ & Lyon-7470 & d5 & Vegetal matter* & -13.41 & $2140 \pm 30$ & $131-327 A D$ \\
\hline TR 14 & $696-699$ & UCIAMS-114467 & $\mathrm{d} 4$ & Wood & -24.7 & $1790 \pm 20$ & $137-323 \mathrm{AD}$ \\
\hline TR 14 & $700-707$ & Lyon8777 & d3 & Wood & ND & $1765 \pm 30$ & $209-380 \mathrm{AD}$ \\
\hline TR 14 & $772-765$ & Lyon-8876 & $\mathrm{d} 2 \mathrm{~b}$ & Wood & -25.43 & $1710 \pm 35$ & $248-409 \mathrm{AD}$ \\
\hline TR 14 & $772-765$ & Lyon-8877 & $\mathrm{d} 2 \mathrm{a}$ & Charbon & -26.31 & $2080 \pm 25$ & $176-40 \mathrm{BC}$ \\
\hline TR 14 & $792-787$ & Lyon-8776 & $\mathrm{d} 1$ & Posidonia* & ND & $2250 \pm 30$ & $12 \mathrm{BC}-171 \mathrm{AD}$ \\
\hline CT 1 & $344-345$ & Lyon-6869 & ND & Charcoal & ND & $1415 \pm 30$ & $598-659 \mathrm{AD}$ \\
\hline CT 1 & 554 & Lyon-7081 & ND & Wood & ND & $1830 \pm 30$ & $91-246 \mathrm{AD}$ \\
\hline CT 1 & 737 & Lyon-6894 & ND & Charcoal & ND & $1940 \pm 30$ & $3-126 \mathrm{AD}$ \\
\hline CT 1 & 792 & Lyon-6895 & ND & Seed & ND & $1920 \pm 30$ & $24-130 \mathrm{AD}$ \\
\hline CT 1 & $1158-1160$ & Lyon-6870 & ND & Charcoal & ND & $4030 \pm 30$ & $2619-2473$ ВС \\
\hline
\end{tabular}

process that is both marine and fluvial. From 18,000 to 7000 BP the rapid rise in sea level at the end of the last glaciation caused the inundation of the ice age delta. The following decrease in rate of sea level rise between 7000 and 5000 BP favored a dominant contribution of fluvial sediments, and allowed the Tiber delta to prograde (Bellotti et al., 2007).

A recent synthesis of the latest paleo-environmental studies, based on ostracod assemblages occurring in the sediments of Portus (Goiran et al., 2010; Mazzini et al., 2011; Pepe et al., 2013), can be found in Salomon et al. (2012). The two harbor basins of Claudius and Trajan (Fig. 1) are very different: whereas the environment of the Claudius harbor is clearly marine, that of the Trajan basin is brackish with temporary incursions of freshwater. As attested to by sediment grain size, the water energy regime is also very different in each harbor: in the Claudius basin, sediments are dominated by sands, whereas harbor muds are prevalent in the access channel to the Trajan basin. The differences in the sedimentology of the two basins are accounted for by their respective configurations at the time they were constructed. The passes of the Claudius harbor allowed entry of seawater through tractive coastal currents, whereas the closed Trajan basin had only limited marine input and hence was dominated by freshwater introduced mainly during Tiber floods (Mazzini et al., 2011; Salomon et al., 2012).

In $62 \mathrm{AD}$ Tacitus (Annales, $\mathrm{XV}, 18$ ) reports the loss of 200 ships in the Claudius harbor during a storm, prompting the construction of the inland Trajan basin. Although the coastal position still leaves the basin vulnerable to tsunamis, with one such event well recognized in 248 AD (Caputto and Faita, 1982), the lack of coarse gravels and sediment sorting, and the good preservation of ostracods (Goiran, 2012) are strong evidence against violent flow conditions. In contrast, the historical record is replete with accounts of the Tiber overflowing its banks (Aldrete, 2007), such as during the major flood of 856, which was strong enough to overrun the harbor infrastructures.

\section{Materials and methods}

In this work, we combine the TR14 core geochemical record with grain-size distributions and ostracod data to reconstruct the changing environment of the access channel to the Trajan basin.

\subsection{Granulometric analyses}

The grain-size distributions of the samples from TR14 were determined by sieving $30 \mathrm{~g}$ of sediments using two sieves with meshes of $0.063 \mathrm{~mm}$ and $2 \mathrm{~mm}$ separating clay from silt and sand. The fraction $<1.6 \mathrm{~mm}$ was analyzed by laser granulometry. For each sample, $5 \mathrm{~g}$ of sediment were weighed and treated several times with $\mathrm{H}_{2} \mathrm{O}_{2}$ to remove organic material. The samples were rinsed with water to eliminate chlorine, which promotes colloidal destabilization, and the suspended particles were deflocculated with $40 \mathrm{ml}$ of $0.1 \mathrm{~N} \mathrm{KCl}$ and again with $40 \mathrm{ml}$ of $0.02 \mathrm{~N} \mathrm{KCl}$. Finally, sediment dispersion was completed in $40 \mathrm{ml}$ of $0.055 \mathrm{~N} \mathrm{NaPO}_{3}$. Once the samples had been agitated for four hours, they were measured by a Malvern Mastersizer 2000 laser granulometer.

\subsection{Radiocarbon dating}

Carbon-14 ages for TR14 were obtained on the linear accelerator of Saclay on fragments of wood, charcoal, plant matter, and Posidonia and are shown in Table 1 and Figs. 2 and 3. The $\delta^{13} \mathrm{C}$ data were provided by the Laboratoire de Mesure du ${ }^{14} \mathrm{C}$ at Saclay and the Laboratoire de Géologie de Lyon (C. Lécuyer and F. Martineau). Errors on raw radiocarbon ages BP are reported at the 95 percent confidence level (two sigmas). The measured ${ }^{14} \mathrm{C}(\mathrm{BP})$ ages were converted into $\mathrm{BC}-\mathrm{AD}$ dates using the continental and marine curves of Reimer et al. (2009) using the Clam software (Blaauw, 2010).

\subsection{Major and trace element analyses}

Sample dissolution and other manipulation were carried out in a class 1000 laboratory under laminar flow hoods. Aliquots of $100 \mathrm{mg}$ sediment samples from TR14 were dissolved in a 3:1:0.5 mixture of concentrated $\mathrm{HF}, \mathrm{HNO}_{3}$, and $\mathrm{HClO}_{4}$ in Savillex beakers left on a hotplate at $120-130^{\circ} \mathrm{C}$ for $48 \mathrm{~h}$, then evaporated to dryness. Perchlorates and any remaining fluorides were converted to chlorides by drying down with $6 \mathrm{~N} \mathrm{HCl}$. The samples in solution in $6 \mathrm{~N} \mathrm{HCl}$ were all clear, attesting to their complete breakdown. Finally, the samples were redissolved in $2 \mathrm{ml}$ concentrated $\mathrm{HNO}_{3}$, from which $\sim 10$ percent aliquots were further diluted in $2 \% \mathrm{HNO}_{3}$ and internal standards (10 ppm Sc for ICP-AES and $2 \mathrm{ppb}$ In for Q-ICP-MS) added. Major elements were analyzed by ICP-AES (ICAP 6000) and trace elements by ICP-MS (Agilent $7500 \mathrm{CX}$ ). The upper limit of blank contribution is negligible for major elements and $<2$ percent of the sample content for trace elements.

In order to reduce the dimensionality of the major and trace element analyses while keeping the essence of the covariance structure and to identify groups of samples with similar geochemical properties, we processed the data through Principal Component Analysis (PCA), Factor Analysis, and Hierarchical Cluster Analysis. The general principles of these techniques (e.g., Johnson and Wichern, 2007) are reviewed in the Appendix. 


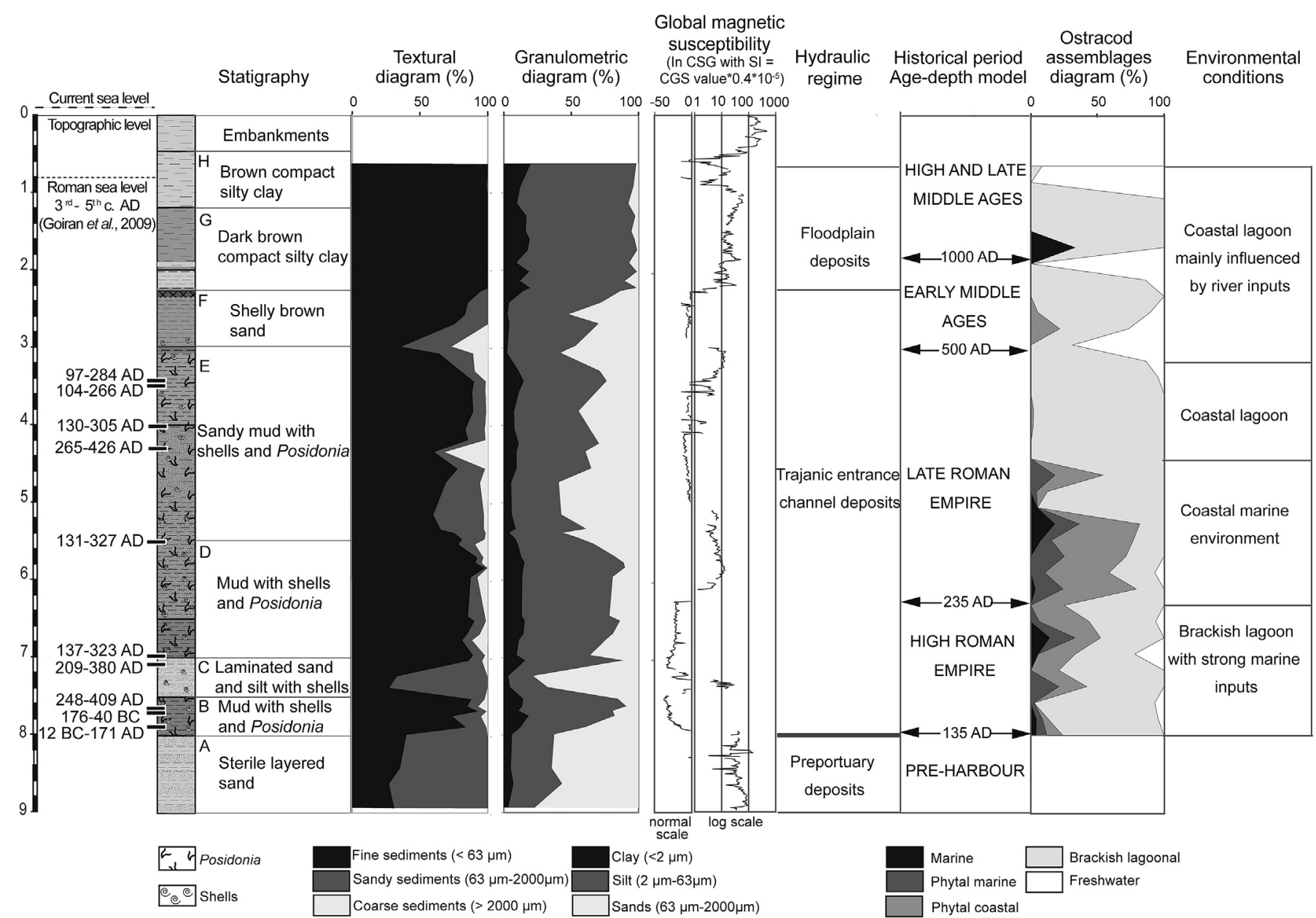

Fig. 2. Stratigraphic log of core TR14 showing the ${ }^{14} \mathrm{C}$ ages, the grain-size distributions with their implications for the hydraulic regime of the harbor, and the distributions of ostracods with inferred environmental conditions.

\subsection{Ostracod analyses}

Ostracod assemblages were described for 36 samples from TR14. The sediments were first disaggregated in $5 \% \mathrm{H}_{2} \mathrm{O}_{2}$, washed on a $63 \mu \mathrm{m}$ mesh, then dried. When possible, at least 50 ostracod valves/ sample were handpicked under the stereomicroscope and identified. Each species frequency was normalized to $1 \mathrm{~g}$ of dried sieved sample and the relative percentage of each taxon was determined. The four main ecological groups typical of marginal marine environments (marine coastal, marine lagoonal, brackish lagoonal, and freshwater) were distinguished using the ecological tolerances of the dominant autochthonous species (Mazzini et al., 2011).

\section{Results}

\subsection{Grain size analysis}

Eight sedimentary units labeled A to $\mathrm{H}$ were defined for TR14 as a function of grain size (Fig. 2, Table 1 in Supplementary Materials). Unit A (900 cm-798 cm) corresponds to very fine, sterile, yellow sands. The average grain size lies between 80 and $120 \mu \mathrm{m}$. An abrupt contrast is noticed with units B $(797 \mathrm{~cm}-750 \mathrm{~cm})$ and D $(699 \mathrm{~cm}-550 \mathrm{~cm})$, which are composed of greyish mud containing Posidonia and shell debris. $80 \%$ of the particles are fine $(<64 \mu \mathrm{m})$ and the average grain size is $12 \mu \mathrm{m}$. Units B and D are themselves separated by the sandy unit C $(749 \mathrm{~cm}-700 \mathrm{~cm})$, less rich in shell debris and in which the average grain size is $\sim 100 \mu \mathrm{m}$. Units $\mathrm{E}$ $(549 \mathrm{~cm}-307 \mathrm{~cm})$ and $\mathrm{F}(306 \mathrm{~cm}-230 \mathrm{~cm})$ are similar to the preceding units, except that they are more sandy, as the proportion of fine particles is $60 \%$ and the average size of the particles is $40 \mu \mathrm{m}$. The upper part of the core (units $\mathrm{G}$ and $\mathrm{H}$ ) is characterized by layers of silts and clays for which the average grain size is $10 \mu \mathrm{m}$.

The harbor deposits (units B to F) show a massive sedimentary structure typical of a slow and continuous sedimentation. The grain size data have been interpreted by Salomon et al. (2012) as reflecting an overall calm environment, dominated by uniform suspension deposits. Rare flood events show up as graded deposits with occasional indications of rolling conditions.

\subsection{Radiocarbon ages}

Some of the ages have been established on Posidonia remains with normal $\delta^{13} \mathrm{C}$ values (Cooper and DeNiro, 1989; Vizzini et al., 2003). We assumed that the remains of these seaweeds floated from the sea into the harbor and hence derived their ${ }^{14} \mathrm{C}$ from the Mediterranean of the Claudius harbor, which was open to the sea (Keay et al., 2005). The other samples, notably d2a, d2b, d3, and d4, are derived from terrestrial plants. The reservoir-corrected ${ }^{14} \mathrm{C}$ age (12 BC-171 AD) measured for the lowest Posidonia d1 (792$787 \mathrm{~cm}$ ) at the base of layer B in the TR14 core is consistent with the historically recorded period of harbor excavation during the Trajan reign (98-117 AD) (Juvenal, Saturae, XII, 75-78; Lugli and Filibeck, 
1935; Keay et al., 2005) (Fig. 2). The two samples d2a and d2b were extracted from the same layer and nevertheless give two very different ages, both the youngest and the oldest over the range d1$\mathrm{d} 4$, which is a strong indication that this layer reflects dredging. The radiocarbon ages (BP) of $\mathrm{d} 3$ and $\mathrm{d} 4$ are indistinguishable at the $95 \%$ confidence level. The confidence interval on their mean (1782 \pm 17 $\mathrm{BP}$ ) corresponds to a time span of 209-329 AD (91\% confidence level). The age of sample $\mathrm{d} 2 \mathrm{~b}$ is the most recent (248-409 AD at the $95 \%$ confidence level) and therefore assigns a maximum age to the time of dredging.

A second dredging phase is attested to by the age of samples d5d8b. The three Posidonia samples d5, d7, and d8a, and the nondescript but marine organic material give indistinguishable radiocarbon ages ( $2152 \pm 12 \mathrm{BP}$ ) corresponding to the interval 138-264 $\mathrm{AD}$, which is likely to be the mean age of sedimentation of the original muds. Sample d6, is, however, significantly younger (265$426 \mathrm{AD}$ ) and assigns a maximum age to the second phase of dredging. Similar dredging phases have been recognized through age inversions in other Mediterranean harbors (Morhange and Marriner, 2009) and in particular in Portus (Goiran et al., 2010; Sadori et al., 2010; Keay and Paroli, 2011; Mazzini et al., 2011; Pepe et al., 2013). Whether the two phases belong to the same period cannot be resolved owing to the uncertainties on the ages of the two dredging phases.

To a large extent, radiocarbon does not seem capable of establishing a precise chronology within the early sediments of the harbor. Some age constraints can nevertheless be inferred from a comparison of the radiocarbon ages of similar material, namely that of Posidonia remains. The difference between the BP radiocarbon ages of sample $\mathrm{d} 1 \mathrm{taken}$ at the very base of the harbor section and those of d5, d7, and d8a is rather well constrained to $\sim 100 \pm 35$ years. Notwithstanding the uncertainties on dates introduced by dendrochronology (e.g., Stuiver and Becker, 1986), such a narrow interval of radiocarbon ages should remain associated with a rather short time interval: it is likely that the sediments between 792 and $344 \mathrm{~cm}$ were deposited during the $2 \mathrm{nd}$, the $3 \mathrm{rd}$, and possibly up until the early 4 th century AD. It is near the end of this period that the dredging operations must have taken place.

The top of the core could also benefit from age constraints stronger than those provided by the ${ }^{14} \mathrm{C}$ dates. The correlation of core TR14 with core CT1 taken in the Canale Trasverso (Salomon et al., 2012) provides such a constraint and considerably strengthens the age-depth model, as CT1 also underwent ${ }^{14} \mathrm{C}$ dating. Again, the age of the seed at the base of CT1's layer B is consistent (25 AD-130 AD) with the beginning of harbor occupation. The remarkable high-Ca, high-Sr layer observed as unit $\mathrm{F}$ in TR14 is also observed as unit D $(240-500 \mathrm{~cm})$ in CT1, although with a smaller $\mathrm{Ca}$ and $\mathrm{Sr}$ excess. An age of 600-660 AD found at $344 \mathrm{~cm}$ within unit D of CT1 by Salomon et al. (2012) is consistent with the age-depth model adopted in the present work for TR14. The thickness of sediment accumulated in the harbor between the onset of its occupation and the top of the high-Ca, high-Sr units (Fig. 3) is similar for the two cores. A roughly uniform sedimentation rate is precisely what is expected from cores drilled in the same basin and distant from each other by no more than a few hundred meters.

The TR14 core was accordingly subdivided into four historical periods: the Early (135 AD-235 AD) and Late (235 AD-500 AD)

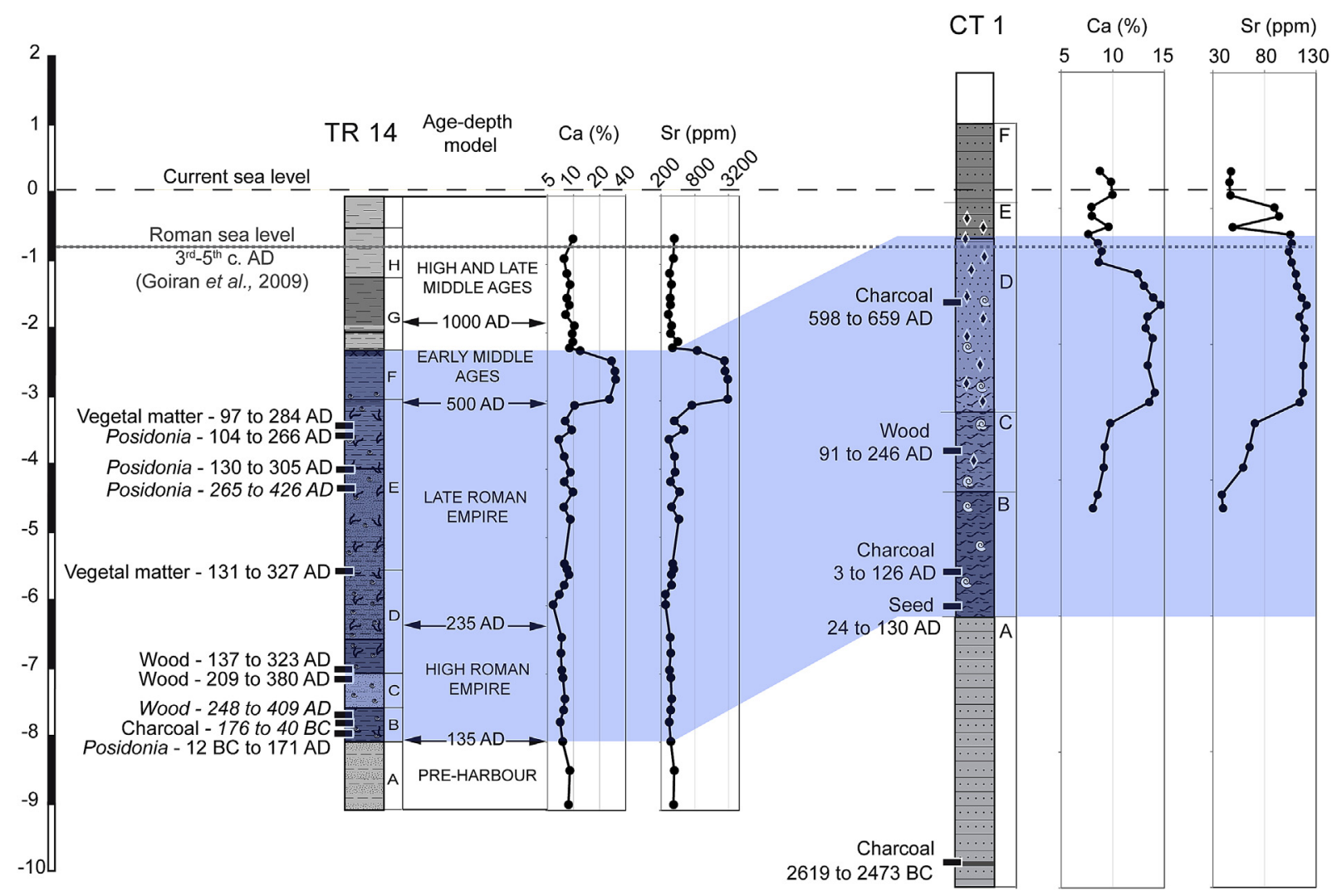

Fig. 3. Geochemical correlation between the TR14 and CT1 cores. The common Ca-Sr peak (blue shading) during the medieval period confirms the chronostratigraphical model of the TR14 core. Unit labeling of TR14 is from the present work; labeling of CT1 is from Salomon et al. (2012). The blue shading highlights the sediments deposited between the initial occupation of the core and the top of the high-Ca, high-Sr units F (TR14) and D (CT1). (For interpretation of the references to color in this figure legend, the reader is referred to the web version of this article.) 


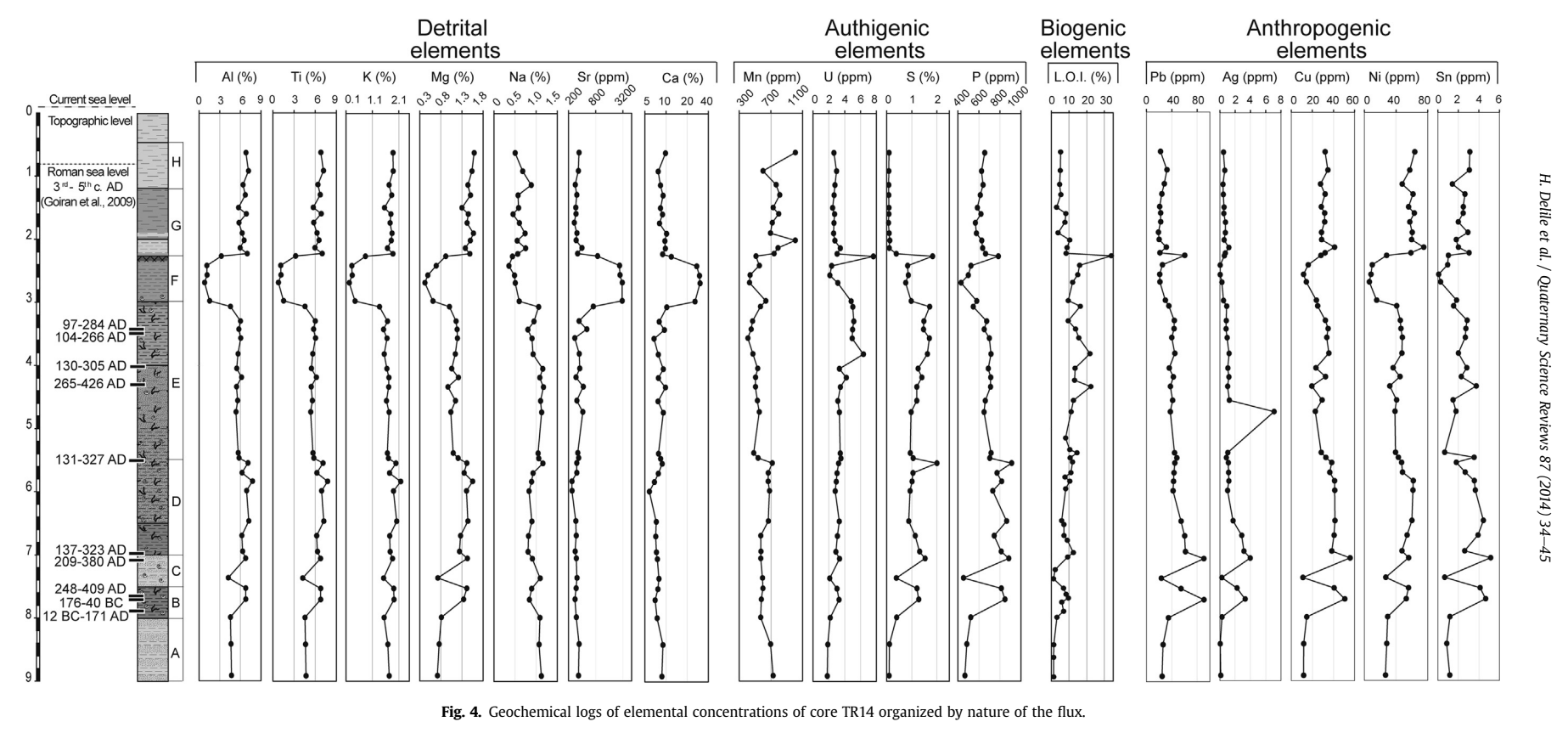


Roman Empire and the Early (500 AD-1000 AD) and High and Late (1000 AD-1500 AD) Middle Ages. The central part of the sedimentary record $(800-300 \mathrm{~cm})$ of TR14 corresponds to sediments deposited during the Empire.

\subsection{Ostracods and geochemistry}

The ostracod assemblages attest to several phases of environmental conditions (Fig. 2, Table 2 in Supplementary Materials) that can be identified through the autoecological analysis of the 25 recognized taxa and their classification into four ecological groups (Mazzini et al., 2011). From the bottom to a depth of $643 \mathrm{~cm}$, ostracods point to brackish lagoon conditions influenced by strong marine inputs, as shown by the alternate dominance of Cyprideis torosa and Pontocythere turbida, a typical phytal ostracod often found together with the aquatic plant Posidonia oceanica. From 600 to $454 \mathrm{~cm}$, the coastal marine character of the environment becomes more entrenched. This likely reflects the establishment of the harbor activities and their maintenance. The stability of the environment remains evident in the subsequent group, from 435 to $305 \mathrm{~cm}$, characterized by the dominance of $C$. toros $a$ and the lack of freshwater influence. From $300 \mathrm{~cm}$ upward, although brackish influence is still noticeable, typical freshwater ostracod assemblages (Candona sp. and Pseudocandona marchica) attest to freshwater conditions, typically those of a freshwater marsh.

Fig. 4 and Table 3 (Supplementary Materials) present selected major and trace element concentrations to which we have added the Loss on Ignition (L.O.I.) that gives a crude measure of the organic content of the sediment. Strong correlations are observed among some elements, notably the limestone group $\mathrm{Sr}$ and $\mathrm{Ca}$ (correlation coefficient $r=+0.99$ ), the detrital group $\mathrm{Al}, \mathrm{Ti}, \mathrm{K}, \mathrm{Mg}$, $\mathrm{Ni}, \mathrm{Zn}, \mathrm{Cr}$, Co, and $\mathrm{La}(r>0.9)$, and elements indicative of poor ventilation such as $U$ and L.O.I. $(r=+0.75)$. In order to simplify the description of the results, we first ran a Principal Component Analysis (e.g., Johnson and Wichern, 2007) (Fig. 5) which extracted different groups of elements: (1) Ca and $\mathrm{Sr}$, (2) $\mathrm{Na}$, (3) Mn, (4) S, U, and L.O.I., (5) Pb, Ag, Cu, and As, and (6) the rest of the elements. Calcium and $\mathrm{Sr}$ are negatively correlated with the detrital elements. Manganese is negatively correlated with S, U, and L.O.I., which makes this direction a consistent indicator of oxygen availability.

Units A, at the base of TR14, and units $\mathrm{G}$ and $\mathrm{H}$, at the top of TR14, define a high-Mn group. Units F, G, and $\mathrm{H}$ are markedly poor in $\mathrm{Na}$ relative to the underlying units, which is consistent with observations on ostracods in the same units pointing to a freshwater environment. Unit $\mathrm{F}$ is a well-defined $\mathrm{Ca}, \mathrm{Sr}$-rich group with abundant carbonates and a correlative depletion of all other elements. It can be correlated with the D unit of the CT1 core (Salomon et al., 2012), which is also particularly rich in Ca and Sr (Fig. 3, Table 4 in Supplementary Materials). Units F, G, and $\mathrm{H}$ are clearly distinct from the harbor muds of units $\mathrm{B}$ an $\mathrm{E}$, which correspond to the period of harbor occupation. Running the factor analysis with ostracod data added to the geochemical data shows a strong correlation between the $\mathrm{Ca}, \mathrm{Sr}$-rich unit $\mathrm{F}$ and the 'brackish lagunar' and 'freshwater' species, whereas the 'marine', 'phytal marine' and 'phytal coastal' groups are strongly correlated with the $\mathrm{Na}$ component.
A

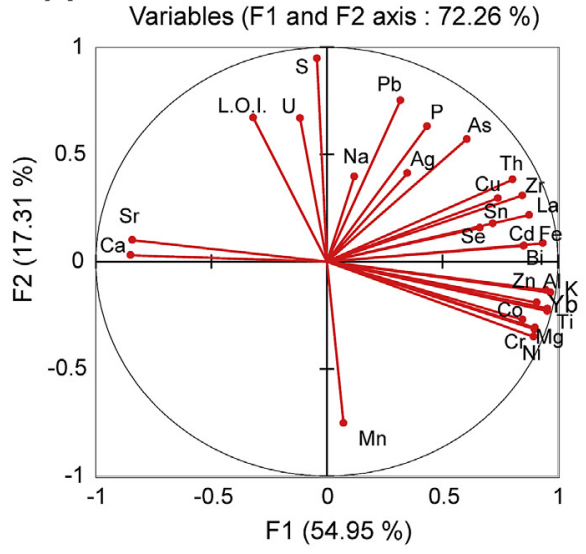

B

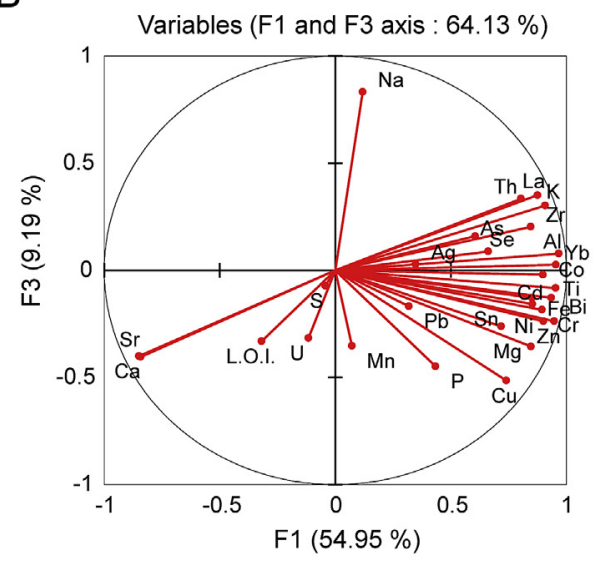

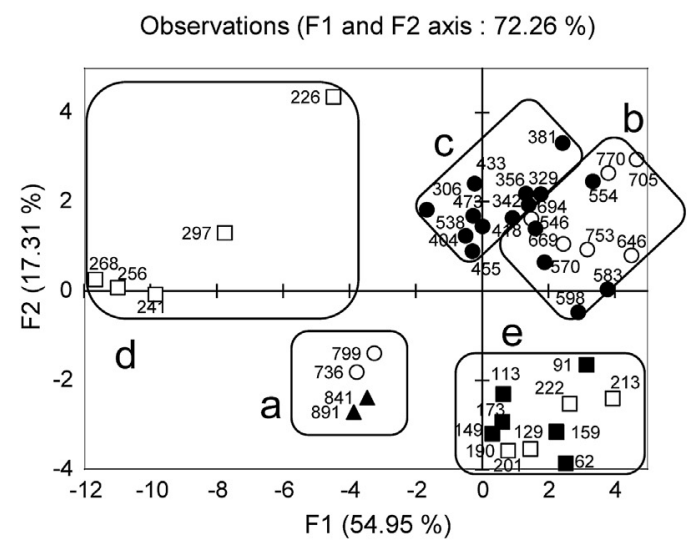

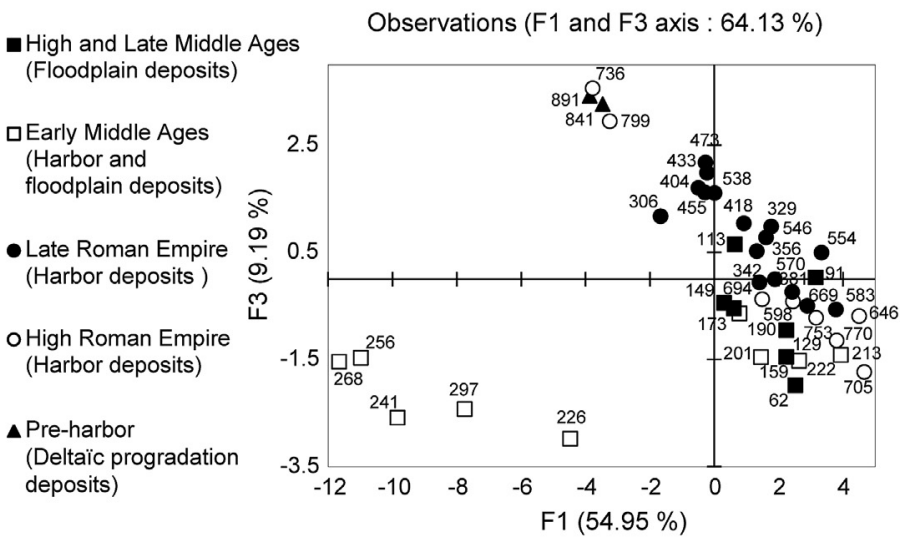

Fig. 5. Principal Component Analysis of elemental concentrations in the TR14 core. Groups of elements and sedimentary episodes can be clearly related to stratigraphy. 


\section{Discussion}

Hierarchical Ascendant Classification (cluster analysis) helps break down the geochemical data (e.g., Johnson and Wichern, 2007) into five groups (a, b, c, d, e) (Fig. 5). Group a at the base of TR14 $(891-736 \mathrm{~cm})$ can be identified with the marine, preharbor Mn-rich unit A. At the top, group e $(222-62 \mathrm{~cm})$ can be identified with the flood plain deposits of units $G$ and $H$. Group d $(226-297 \mathrm{~cm})$ corresponds to the carbonate-rich unit F. Abundant Ca causes a visible dilution of the other elements, notably those of detrital character. Groups b (770-546) and c (538$306 \mathrm{~cm}$ ) correspond to the harbor activity. There is only minor depth overlap between the groups and only one outlier (226). Principal Component Analysis restricted to major elements brings the two outliers back into their natural groups. Alternatively, these samples may correspond to isolated floods or dredging events.

Factor analysis helps understand how the various groups discussed so far differ (Albarède, 1996). We found only four significant factors (Fig. 6A):

(1) A dominant factor F1 opposing the detrital elements to $\mathrm{Ca}$ and $\mathrm{Sr}$ (carbonates).

(2) A factor F2 opposing Mn to the group of elements immobile under dysoxic conditions in the sediments (L.O.I., U, S). This factor is a measure of oxic diagenesis in sediments (Calvert and Price, 1977) and therefore also accounts for the preservation of organic material.

(3) A factor F3 opposing Na to the rest of the elements, but in particular $\mathrm{Ca}, \mathrm{Sr}$, and $\mathrm{Mn}$. This factor reflects either the salinity of the harbor itself or the invasion of the sediments by the salt wedge.

(4) A factor F4, which opposes Pb and Ag, two metals commonly extracted from the same ores, the bronze metals $\mathrm{Cu}$ and $\mathrm{Sn}$, and $\mathrm{P}$ and $\mathrm{Mn}$. This factor represents a clear anthropogenic signal. The negative correlation of this signal with Mn reflects that these metals remain insoluble under reducing conditions.

Principal Component Analysis was also carried out for the geochemical and ostracod data of the harbor units $\mathbf{b}$ and $\mathbf{c}$ (Fig. 7). A plot of the first two factors now splits group $\mathbf{c}$ into sub-groups $\mathbf{c}_{\mathbf{A}}$ and $\mathbf{c}_{\mathbf{B}}$, thereby suggesting the existence of three harbor groups:

(i) The 'first harbor' sequence b $(770-556 \mathrm{~cm})$, dominated by a strong detrital component rich in $\mathrm{Al}$ and $\mathrm{Ti}$, but also $\mathrm{Mn}$, reflects the importance of flood events.

(ii) The 'second harbor' sequence $\mathbf{c}_{\mathbf{A}}(546-404 \mathrm{~cm})$, dominated by $\mathrm{Na}$ and ostracods of marine affinity, shows the dominance of seawater.

(iii) The 'third harbor' sequence $\mathbf{c}_{\mathbf{B}}(418-306 \mathrm{~cm})$, dominated by elements indicative of oxygen deficiency (S, U, L.O.I.) and ostracods of brackish-lagunar affinity, indicates isolation of the harbor.

Freshwater ostracods thrive in the high-Ca,Sr group d, whereas marine and costal species peak at the transition between the first (b) and the second $\left(\mathbf{c}_{\mathbf{A}}\right)$ harbor series, which is consistent with the high Na content of the latter.

\subsection{The changing sedimentary environment of the harbor}

Group a in Fig. 5 comprises the pre-harbor units B and C and attests to the progradation of the Tiber delta. The rather coarse grain size indicates a high-energy environment. The geochemistry of this group is characterized by high salinity (high Na, F3 in Fig. 5B) and oxic conditions (large F2, high Mn, low TOC, S, P, and U in
A

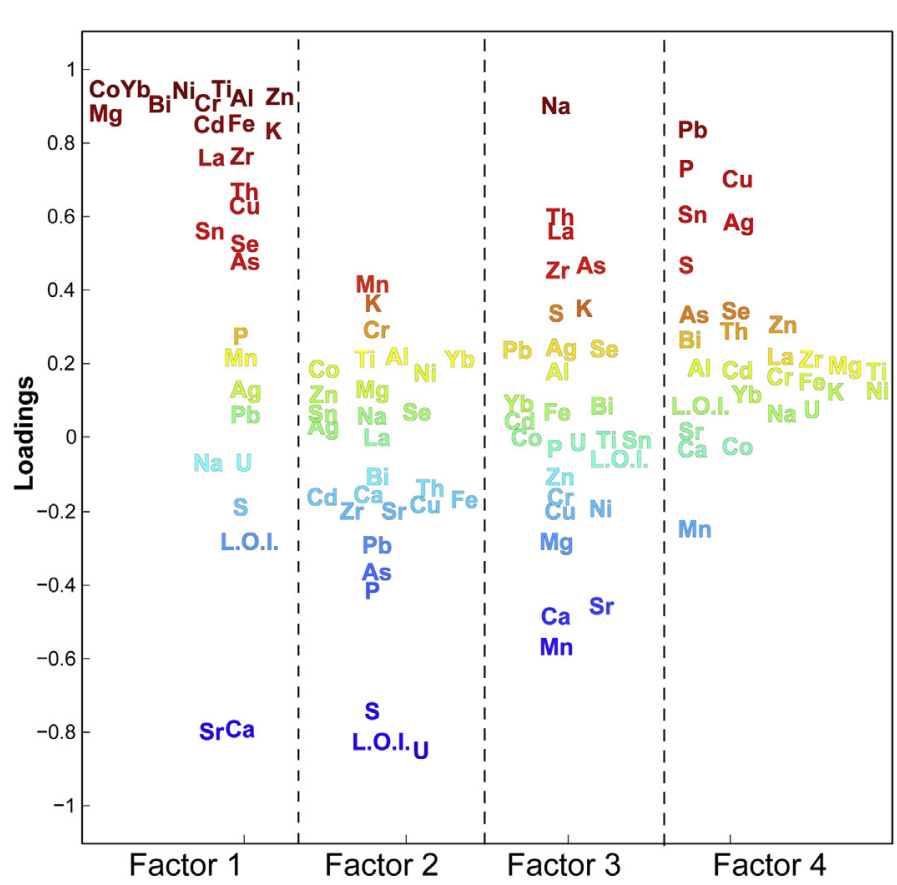

B Factor 1 Factor 2 Factor 3 Factor 4

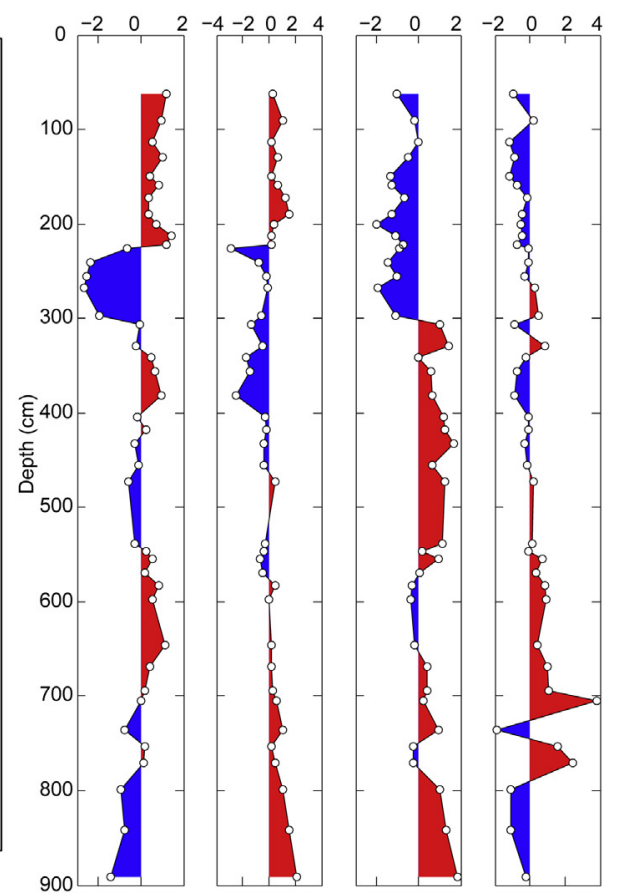

Fig. 6. (A) Factor analysis of elemental concentrations in the TR14 core for 4 factors and varimax rotation. Four groups of elements correspond to different sedimentary factors: (1) silicate detrital fraction (+) vs carbonate fraction $(-),(2)$ oxic $(+)$ vs dysoxic conditions $(-),(3)$ seawater influence, and (4) anthropogenic contribution $(+)$ vs oxic remobilization of metals (-). (B) Log of the four factors showing the succession of different regimes: the pre-portuary estuarine period $(900-800 \mathrm{~cm})$, the busy early imperial harbor supplied with oxygenated freshwater $(770-550 \mathrm{~cm})$ grading into the late imperial harbor $(550-300 \mathrm{~cm})$ in which water became more saline and less oxygenated, a well-defined episode (230$300 \mathrm{~cm}$ ) dominated by salty water and carbonates, and, after the abandonment of the harbor at $230 \mathrm{~cm}$, a flood-plain regime. 

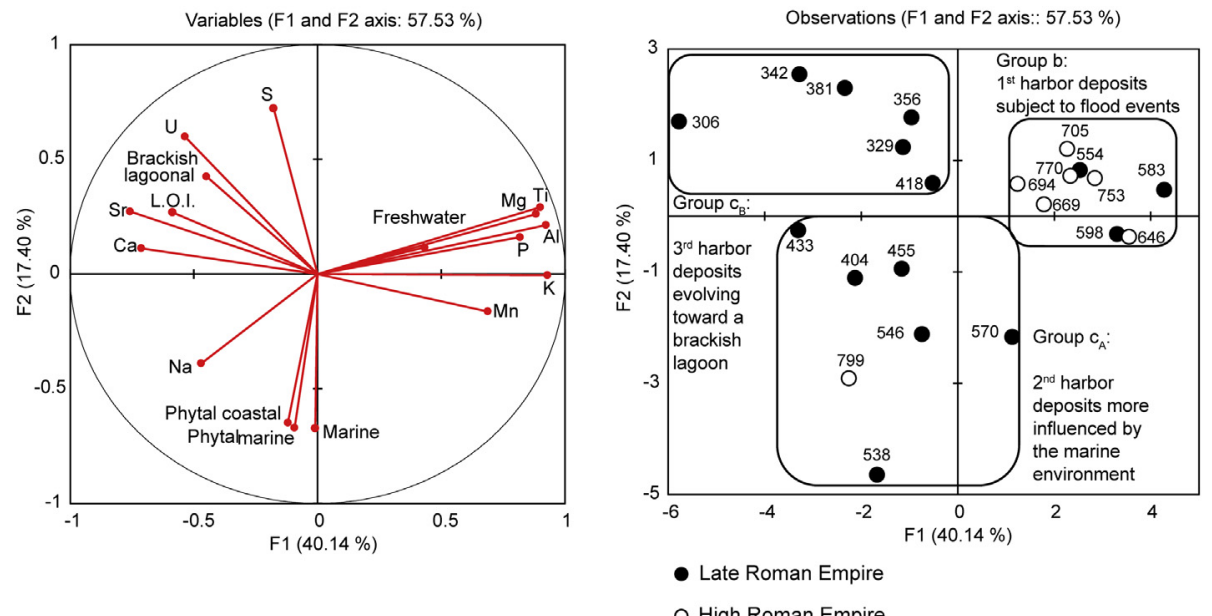

Fig. 7. Principal Component Analysis of elemental concentrations and autoecological groups in the harbor deposits. The left panel corresponds to the correlation graphics of elements and autoecological groups. The freshwater group is clearly associated with the silicate detrital fraction, whereas phytal marine, phytal coastal and marine groups are associated with seawater influence $(\mathrm{Na})$. The brackish lagoonal group is associated with both dysoxic conditions and carbonate fractions. The right panel shows PCA evidence for three clearly distinct periods of harbor activity at 770-554 cm (b), 570-404 cm $\left(\mathbf{c}_{\mathrm{A}}\right)$, and $418-306 \mathrm{~m}\left(\mathbf{c}_{\mathrm{B}}\right)$.

Fig. 5A). These mineralogical and geochemical characteristics are consistent with a turbulent, well-ventilated submerged environment compatible with a delta front in which the fluvial sands are remobilized by the marine swell. As the terrigeneous elements (factor F1) are not prevalent, the oxygenation of the water column likely results from the swell rather than the fluvial inputs of freshwater.

The harbor mud deposits of groups b, c, and d (Fig. 5) show consistent trends with upward decreasing F2 and therefore decreasing oxygenation. A parallel evolution is that of declining anthropogenic input indicated by the decreasing factor F4. These trends are nicely illustrated by increasing TOC and $U$ and concomitant decreases in $\mathrm{P}$ and $\mathrm{Ag}$. These parameters reflect either the progressive confinement of the harbor and the build-up of a stagnant pool of water resulting from the construction of more and more facilities, such as storehouses and official buildings or, more likely, progradation of the delta and the accompanying advance of the shoreline (Giraudi, 2011). Similar geochemical characteristics indicative of anoxic conditions have been observed in the harbor deposits of the antique harbor of Tyre, Lebanon (Elmaleh et al., 2012).

Increasingly reducing conditions can also be accounted for by eutrophication, i.e., the proliferation of photosynthetic organisms and accumulation of organic debris. First, oxygen-deficient conditions in the water column increase the rate of phosphorus recycling, which make up part of the nutrients necessary for the production of organic matter (Ingall and Jahnke, 1997). Second, this feedback combines with the effect of bioturbation, which decreases the carbon content of sediments and promotes phosphate deposition (Ingall et al., 1993). Decreasing oxygen availability is clearly demonstrated by the upward trend of decreasing $\mathrm{P} / \mathrm{C}$ at least up to $\sim 230 \mathrm{~m}$ (Fig. 1, Supplementary Materials). Poorly ventilated conditions in sediments also account for the high concentrations of $S$ and $U$ in the harbor deposits. Sulfur, which is largely in the form of iron sulfide, is produced by the bacterial reduction of marine sulfate, while the soluble hexavalent uranium oxide is reduced to insoluble $\mathrm{UO}_{2}$.

Groups $\mathbf{b}, \mathbf{c}_{\mathbf{A}}, \mathbf{c}_{\mathbf{B}}$, and $\mathbf{d}$ (Figs. 5 and 7) represent different stages in the evolution of the detrital/carbonate factor F1. The second harbor group $\left(\mathbf{c}_{\mathbf{A}}\right)$ and, to an even greater extent, group $\mathbf{d}$ show reduced supply of terrigeneous particles contrasting with groups $\mathbf{b}$ and $\mathbf{c}_{\mathbf{B}}$. Group $\mathbf{b}$ attests to an abundant supply of freshwater. With the exception of the sandy layer corresponding to unit $\mathrm{C}$, the sedimentary load is dominated by fine-grained terrigeneous particles. The positive values of $\mathrm{F} 2$ in this group, which corresponds to the earliest harbor deposits (Fig. 6B), is the most oxygenated layer of the harbor sequence and therefore attests to a fast turnover of the harbor water. Together, these observations constitute clear evidence that the Canale Trasverso was actively used during the High Roman Empire. In addition, the high value of F4 indicates a local source of contamination originating in metallurgical activities at Portus or upstream along the Tiber. A sandy episode corresponding to unit $C$ may correspond to a major flood event.

Group $\mathbf{c}_{\mathbf{A}}$ sees the growing influence of a marine component in the Trajan harbor, both in sediment geochemistry and ostracod populations, and of the anoxic character of the environment. The decreased renewal rate of water in the basin may indicate a silting up of the Canale Trasverso with most of the water exchange taking place through the Claudius harbor.

During the deposition of group $\mathbf{c}_{\mathbf{B}}$, salinity remained rather high (factor F3), but the harbor waters became increasingly stagnant (low values of F2). It is clear that from that point on the Canale Trasverso was essentially decommissioned.

The transition to group $\mathbf{d}$ is characterized by a sudden drop of $\mathrm{Na}$ (factor F3) and the strong development of carbonate sedimentation (low values of F1). Likewise, ostracods show clear freshwater and brackish lagunar conditions. Anoxia reaches its climax. At this stage, the recharge of the Trajan basin depends on low-energy creeks or on communication with local oligohaline marshes. Water is essentially clear of the detrital particles carried by the Tiber. The intense biological activity (eutrophication), probably enhanced by the lack of suspended particles, prominently depletes phosphorus. The harbor therefore seems to be cut off from the sea. At that point, the basin of Trajan was probably supplied by excess of rainwater over evaporation, by sewage discharged after water conveyed by the Portuensis aqueduct had been used, and possibly by the water table.

The abrupt transition to group $\mathbf{e}$ is a clear signal that the harbor in Portus is no longer a site of human activity. The depositional environment is that of freshwater (small values of F3), oxygenated conditions prevail (high values of F2), and detrital particles are abundant (high values of F1). Ostracods likewise reveal an 


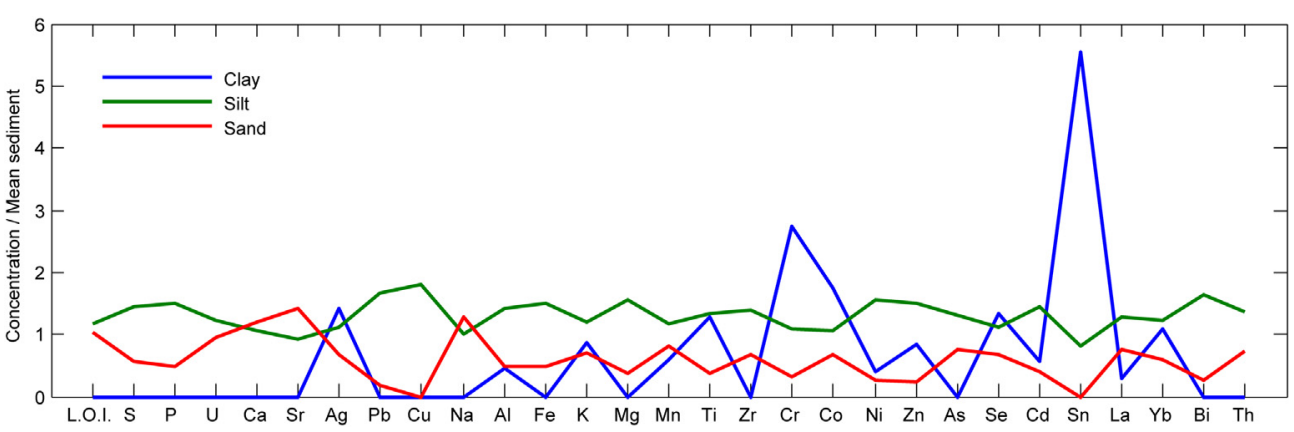

Fig. 8. Breakdown of bulk sediment concentrations into three components, clay, silt, and sand (Eq. (1)). Sediment concentrations are to a large extent accounted for by the silt fraction. Clays carry a strong anthropogenic signal $(\mathrm{Ag}, \mathrm{Cr}, \mathrm{Zn}, \mathrm{Sn})$. The apparent lack of a sand contribution reflects that it is dominated by quartz and feldspar and coarse organic debris.

environment dominated by freshwater and brackish lagoons. The low $\mathrm{P}$ contents are consistent with weak biological productivity. These characteristics indicate that the abandoned harbor has finally been overrun by the flood plain.

\subsection{From geochemistry to mineral carriers}

In order to assign the different elements to their potential mineral carriers (Albarède, 1996), we broke down the major and trace element composition of each sample of the harbor groups into a mixture of grain-size fractions, clay silt, and sand. We used Matlab software to solve by non-negative weighted least-square the following system of equations relating the concentration $C_{k}^{i}$ of the $i-$ th element $(i=1 \ldots n)$ in the $k$-th sediment $(k=1 \ldots s)$ to the concentration $c_{j}^{i}$ of the $i$-th element in the $j$-th mineral component $\left(j=\right.$ clay, silt, sand) via the modal proportion $X_{k}^{j}$ of this component measured in the $k$-th sample:

$C_{k}^{i}=X_{k}^{\text {clay }} c_{\text {clay }}^{i} X_{k}^{\text {silt }} c_{\text {silt }}^{i}+X_{k}^{\text {sand }} c_{\text {sand }}^{i}$

This equation simply expresses that each sample represents an aggregate of its clay, silt, and sand fractions, and that the concentration of a chemical element in the sediment is the sum of the concentration of the chemical element in each mineral component weighted by the abundance of the component in the sample. We assumed that the compositions of the mineral components have not evolved over time. The compositions of the mineral fractions $c_{j}^{i}$ are plotted in Fig. 8 after normalization to the average sediment composition. The rather flat pattern of the silt fraction indicates that it carries most of the geochemical signal of the rock, which is another way to emphasize the prevalence of the detrital elements. With due notice that quartz represents a dilution factor, the sand fraction accounts for $\mathrm{Sr}$ and $\mathrm{Ca}$, and therefore must contain carbonates, and $\mathrm{Na}$ attests to the contribution of coarse material to porosity. The fine-grained clay fraction shows the prevalence of probable metallic pollution ( $\mathrm{Sn}, \mathrm{Zn}, \mathrm{Ag}$ ) but also of heavy minerals (Ti, $\mathrm{Cr}, \mathrm{Yb})$.

Sands are, as expected, negatively correlated with both clays and silts $(r \sim-1.0)$ (Table 2). Clay and silt fractions are strongly correlated $(r=+0.91)$ and therefore should not be considered independent variables. The positive correlations between $\mathrm{Mg}$ $(r=+0.89), \mathrm{Al}(r=+0.86), \mathrm{Ti}(r=+0.87)$, and $\mathrm{Yb}(r=+0.86)$ on the one hand, and the silt fractions (Table 2) on the other hand, reflect that these elements are not represented in the sand fraction. This indicates that the easily weathered $\mathrm{Na}$,Ca-feldspar is not a significant component of sands. As expected from the discussion above, $\mathrm{Sn}$ is correlated with the clay and silt fractions (Fig. 8), which may attest to either the presence of minute grains of natural cassiterite
$\left(\mathrm{SnO}_{2}\right)$ or an anthropogenic origin. Sodium only correlates with the sand fraction (Table 2) and since this element has no nominal mineral carrier this is a strong indication that $\mathrm{Na}$ is introduced by percolation of salty water into porous coarse sedimentary layers either because overlying water is of marine or brackish origin or because of infiltration of the littoral salt wedge. Calcium and $\mathrm{Sr}$ do not correlate significantly with mineral fractions. Because carbonate/quartz ratios vary up the sediment core, this observation does not conflict with the previous observation that sands contain a carbonate fraction.

\subsection{Historical implications}

The fluvial harbor at the mouth of Ostia, after its general siltingup, was abandoned in the late 1 st $\mathrm{c}$. BC and the early 1 st c. AD (Goiran et al., 2014). Goiran et al. (2014) proposed that the infilling is explained by a succession of major flood episodes at the beginning of the Imperial Period. These observations corroborate the

Table 2

Correlation table of elements and granulometric size classes (sand, silt, and clay). The most significant correlations are given, i.e., $r<0.6$ or $r>0.6$.

\begin{tabular}{|c|c|c|c|c|c|}
\hline \multicolumn{3}{|c|}{ Positive $r$} & \multicolumn{3}{|c|}{ Negative $r$} \\
\hline Silt & Clay & 0.91 & $\mathrm{Na}$ & Silt & -0.62 \\
\hline Mg & Silt & 0.89 & $\mathrm{Na}$ & Clay & -0.65 \\
\hline $\mathrm{Ti}$ & Silt & 0.87 & K & Sand & -0.68 \\
\hline $\mathrm{Zn}$ & Silt & 0.87 & Co & Sand & -0.7 \\
\hline $\mathrm{Al}$ & Silt & 0.86 & $\mathrm{Bi}$ & Sand & -0.71 \\
\hline $\mathrm{Yb}$ & Silt & 0.86 & $\mathrm{P}$ & Sand & -0.76 \\
\hline $\mathrm{Cu}$ & Silt & 0.85 & Sn & Sand & -0.8 \\
\hline $\mathrm{Ni}$ & Silt & 0.85 & $\mathrm{Cr}$ & Sand & -0.83 \\
\hline $\mathrm{Cr}$ & Silt & 0.82 & $\mathrm{Cu}$ & Sand & -0.84 \\
\hline $\mathrm{Ti}$ & Clay & 0.82 & $\mathrm{Ni}$ & Sand & -0.84 \\
\hline $\mathrm{Cr}$ & Clay & 0.81 & $\mathrm{Al}$ & Sand & -0.85 \\
\hline $\mathrm{Zn}$ & Clay & 0.81 & $\mathrm{Yb}$ & Sand & -0.86 \\
\hline $\mathrm{Yb}$ & Clay & 0.8 & $\mathrm{Ti}$ & Sand & -0.87 \\
\hline Sn & Silt & 0.79 & $\mathrm{Mg}$ & Sand & -0.88 \\
\hline $\mathrm{Al}$ & Clay & 0.78 & $\mathrm{Zn}$ & Sand & -0.88 \\
\hline Mg & Clay & 0.78 & Sand & Clay & -0.94 \\
\hline $\mathrm{Ni}$ & Clay & 0.77 & Sand & Silt & -1 \\
\hline$P$ & Silt & 0.77 & & & \\
\hline Sn & Clay & 0.77 & & & \\
\hline $\mathrm{Cu}$ & Clay & 0.75 & & & \\
\hline $\mathrm{Bi}$ & Silt & 0.72 & & & \\
\hline $\mathrm{Bi}$ & $\mathrm{Cd}$ & 0.69 & & & \\
\hline Co & Silt & 0.69 & & & \\
\hline Co & Clay & 0.68 & & & \\
\hline K & Silt & 0.68 & & & \\
\hline $\mathrm{P}$ & Clay & 0.65 & & & \\
\hline $\mathrm{Bi}$ & Clay & 0.64 & & & \\
\hline $\mathrm{Na}$ & Sand & 0.64 & & & \\
\hline K & Clay & 0.63 & & & \\
\hline
\end{tabular}


work of Le Gall (1953), who showed that at the beginning of the first century AD up to the late Roman Empire, floods of the Tiber became more frequent. This trend may reflect large-scale climatic change, as increasingly frequent floods also affected the Rhone river (Bravard et al., 1992; Bruneton et al., 2001) and its delta (ArnaudFassetta, 2002) during the same period. Likewise, Benvenuti et al. (2006) and Lippi et al. (2007) demonstrated the occurrence of strong floods of the Arno river in sediments of the ancient Pisa harbor contemporaneous with those of Portus. The occasional input of freshwater into the harbor during the High Roman Empire and part of the late Roman Empire at Portus can therefore be accounted for by Tiber floods.

The second harbor sequence $\mathbf{c}_{\mathbf{A}}$ seems to date from the late Roman Empire. The more marine environment and the correlatively decreasing input of freshwater may reflect less frequent floods of the Tiber beginning in the 3rd c. AD (Le Gall, 1953; Bersani and Benvivenga, 2001; Aldrete, 2007) and the silting-up of the Canale Trasverso, leading to the emergence of a stable environment.

The third and last functional harbor phase, corresponding to group $\mathbf{c}_{\mathbf{B}}$, may be interpreted as sustaining the formation of an alluvial plug, possibly at the intersection of the Canale Trasverso and the Fossa Traiana in such a way that the freshwater of the Tiber could not reach the harbor. We suggest that, at this stage, silting had already reduced the draft and made navigation in the harbor difficult. With the caveat of having to take into account the precision on the ${ }^{14} \mathrm{C}$ ages, this episode may correspond to the period of decreased activity in the harbor at the end of the third century noted by Keay and Paroli (2011). The harbor probably lost some of its activity in the late Roman Empire and became isolated from the Tiber (with the probable exception of water from the aqueducts) and increasingly confined. Extreme conditions are depicted in the fresco painted by Danti in 1582, in which the basin of Claudius is sealed off, presumably by the coastal transport of the sands present in the sediment cores described by Goiran et al. (2010), while Trajan's hexagonal basin and its access channel eventually were reduced to an isolated pond.

Silting-up and lack of maintenance of the Canale Trasverso support the idea of a progressive abandonment, which was complete by the Early Middle Ages (Mazzini et al., 2011). Parallel to this isolation of the fluvial sources, the study of the deltaic plain of the Tiber has revealed an important phase of progradation of the coastline at the end of Antiquity (Bellotti et al., 2007), which added to the isolation of the harbor basin of Trajan from marine influence.

\section{Conclusions}

The present study shows that the geochemistry of harbor sediments combined with ostracod inventories and grain-size distributions provides valuable information on the paleo-environmental dynamics of the water column. We identified three main control factors in the form of salinity and oxygenation of the water column plus the anthropogenic contribution. The harbor environment became increasingly oxygen-deficient in contrast to the wellventilated fluvial environment. Variations in salinity distinguish the nature of the fluvial deposits and the degree of opening to the sea of the harbor environment.

Following the first phase of the harbor, dated from the early Empire and characterized by a brackish environment punctuated by a few fluvial intrusions probably related to increase in flood frequency, the harbor opened to the marine environment during the late Roman Empire. Then, as silting-up progressed, the harbor evolved towards lagoonal conditions with conditions increasingly deficient in oxygen. Hypoxia reached its height in the Early Middle Ages, when Trajan's harbor became a body of water with a negative evaporation balance. We speculate that isolation of the harbor was triggered by the formation of an alluvial plug at the entrance to the Canale Trasverso.

Comparing the geochemical and granulometric data suggests a fluvial origin for the clays and silts in contrast to sands, which were exposed to waters with higher salinity.

The present case study of the Trajan harbor illustrates the pertinence of geochemical data to the reconstruction of the environmental conditions prevalent in antique harbors in general.

\section{Acknowledgments}

We thank the Ecole Française de Rome, the British School at Rome, the University of Southampton, the Soprintendenza Archeologica Speciale di Roma, the ANR Jeune Chercheur and the CNRS (AIR Archéométrie and Homere project) for their financial and logistical support. We also thank the ARTEMIS program for carrying out the SMA radiocarbon dating and Elisa Pleuger for help with ostracod extractions. We thank the Institut National des Sciences de l'Univers for supporting the analytical facility at ENS Lyon and Philippe Telouk for making sure instruments were always at their best. Our thoughts go to late Chantal Rabourdin-Combes, who encouraged collaboration between fields and hence scientists that may not otherwise have crossed paths. The particularly wellendowed stacks of the Fondren Library at Rice University greatly facilitated our literature research.

\section{Appendix A. Supplementary data}

Supplementary data related to this article can be found at http:// dx.doi.org/10.1016/j.quascirev.2014.01.002.

\section{Appendix A. Principal Component, Factor, and Cluster Analysis}

These techniques use the fact that the data to be examined are normally distributed in a space with as many dimensions as the number of elements. In Principal Component Analysis the data are first 'whitened' or 'reduced' by removing the mean value and dividing by the standard deviation of each variable. The eigenvalues of the resulting covariance matrix are extracted and ranked in the order of descending values and define the proportion of the total variance assigned to each of these components. The data are then projected into the subspace of the corresponding eigenvectors and usually displayed as 2- or 3-dimensional plots. The closely related approach of Factor Analysis assumes that the total variance of the sample set can be accounted for by a small number of components (here four) and rotates the reduced data in the dimensionallyreduced space to optimize the representation. The scores are the transformed variable values corresponding to a particular sample and loadings are the projection of the standardized unit vector of each original variable onto the factor axis.

Finally, Hierarchical Ascendant Classification (cluster analysis) helps break down the geochemical data into homogeneous groups using statistical distances between these groups. An agglomerative hierarchical algorithm is used which starts by grouping the most similar data and proceeds towards group identification based on their respective distances.

More details on these techniques can be found in a number of textbooks such as that of Johnson and Wichern (2007).

\section{References}

Albarède, F., 1996. Introduction to Geochemical Modeling. Cambridge University Press, Cambridge. 
Aldrete, G.S., 2007. Floods of the Tiber in Ancient Rome, Ancient Society and History. The Johns Hopkins University Press, Baltimore.

Arnaud-Fassetta, G., 2002. Geomorphological records of a "flood-dominated regime" in the Rhône Delta (France) between the 1st century BC and the AD 2nd century. What correlations with the catchment paleohydrology? Geodin. Acta 15, 79-92.

Arnoldus-Huyzendveld, A. 2005. The natural environment of the Agro Portuense. In: Portus, an Archaeological Survey of the Port of Imperial Rome. Archaeological Monographs of the British School at Rome, vol. 15. BSR, London, pp. 1430.

Bellotti, P., Calderoni, G., Carboni, M.G., Di Bella, L., Tortora, P., Valeri, P., Zernitskaya, V., 2007. Late Quaternary landscape evolution of the Tiber River delta plain (Central Italy): new evidence from pollen data, biostratigraphy and $14 \mathrm{C}$ dating. Z. für Geomorphol. 51, 505-534.

Bellotti, P., Mattei, M., Tortora, P., Valeri, P., 2009. Geoarchaeological investigations in the area of the imperial harbours of Rome. Méditerranée 112, 51-58.

Benvenuti, M., Mariotti-Lippi, M., Pallecchi, P., Sagri, M., 2006. Late-Holocene catastrophic floods in the terminal Arno River (Pisa, Central Italy) from the story of a Roman riverine harbour. Holocene 16, 863-876.

Bersani, P., Benvivenga, M., 2001. Le piene del Tevere a Roma dal V secolo a.C. all'ano 2000 (Servizio idrografico e mareografico nazionale). Dipartimento per i Servizi Tecnici Nazionali, Roma.

Blaauw, M., 2010. Methods and code for "classical" age-modelling of radiocarbon sequences. Quat. Geochronol. 5, 512-518.

Bravard, J.-P., Verot-Bourrely, A., Salvador, P.-G., 1992. Le climat d'après les informations fournies par les enregistrements sédimentaires fluviatiles étudiés sur des sites archéologiques, in: Nouvelles De L'archéologie. In: Presented at the Le climat à la fin de l'Age du Fer et dans l'Antiquité (500 BC-500 AD): méthodes d'approche et résultats. Table ronde, Epona, pp. 7-13.

Bruneton, H., Arnaud-Fassetta, G., Provansal, M., Sistach, D., 2001. Geomorphological evidence for fluvial change during the Roman period in the lower Rhone valley (southern France). CATENA 45, 287-312.

Calvert, S.E., Price, N.B., 1977. Geochemical variation in ferromanganese nodules and associated sediments from the Pacific Ocean. Mar. Chem. 5, 43-74.

Caputto, M., Faita, G.F., 1982. Statistical analysis of the tsunamis of the Italian Coasts. J. Geophys. Res. Oceans 87, 601-604.

Cooper, L.W., DeNiro, M.J., 1989. Stable carbon isotope variability in the seagrass Posidonia oceanica: evidence for light intensity effects. Mar. Ecol. Prog. Ser. 50, 225-229.

Cubizolle, H., 2009. Paléoenvironnements, Collection U. Géographie. Armand Colin, Paris.

Delile, H., Blichert-Toft, J., Goiran, J.P., Bravard, J.P., Albarède, F., 2012. The record of human impact in the sedimentary record at Portus, the harbor of ancient Rome. Mineral. Mag. 76, 1640.

Elmaleh, A., Galy, A., Allard, T., Dairon, R., Day, J.A., Michel, F., Marriner, N., Morhange, C., Couffignal, F., 2012. Anthropogenic accumulation of metals and metalloids in carbonate-rich sediments: insights from the ancient harbor setting of Tyre (Lebanon). Geochim. Cosmochim. Acta 82, 23-38.

Giraudi, C., 2011. The sediments of the "Stagno di Maccarese" marsh (Tiber river delta, central Italy): a late-Holocene record of natural and human-induced environmental changes. Holocene 21, 1233-1243.

Giraudi, C., Tata, C., Paroli, L., 2007. Carotaggi e studi geologici a Portus: il delta del Tevere dai tempi di Ostia Tiberina alla costruzione dei porti di Claudio e Traiano. J. Fasti Online, 1-12.

Giraudi, C., Tata, C., Paroli, L., 2009. Late Holocene evolution of Tiber river delta and geoarchaeology of Claudius and Trajan Harbor, Rome. Geoarchaeology 24, $371-$ 382 .

Goiran, J.-P., 2001. Recherches géomorphologiques dans la région littorale d'Alexandrie en Egypte. Université de Provence (Aix-Marseille).

Goiran, J.-P., 2012. Caractérisation d'un dépôt de tsunami dans le port antique d'Alexandrie par l'étude exoscopique des quartz: apports et limites de la méthode. In: Archéosismicité Et Tsunami En Méditerranée: Approches Croisées, pp. $157-190$

Goiran, J.-P., Morhange, C., 2003. Géoarchéologie des ports antiques en Méditerranée: problématiques et études de cas. Topoi, pp. 647-669.

Goiran, J.P., Ognard, C., Tronchère, H., Canterot, X., Cluze, J., 2007. Recent geoarcheological findings of Portus, the ancient Harbour of Rome. In: Presented at the People/environment Relationships from Mesolithic to Middle Ages: Recent Geo-archaeological Findings in Southern Italy, Salerno (Italy), pp. $30-31$.

Goiran, J.-P., Salomon, F., Mazzini, I., Bravard, J.-P., Pleuger, E., Vittori, C., Boetto, G., Christiansen, J., Arnaud, P., Pellegrino, A., Pepe, C., Sadori, L., 2014. Geoarchaeology confirms location of the ancient harbour basin of Ostia (Italy). J. Archaeol. Sci. 41, 389-398.

Goiran, J.P., Tronchère, H., Carbonel, P., Salomon, F., Djerbi, H., Ognard, C., Lucas, G., Colalelli, U., 2008. Portus, la question de la localisation des ouvertures du port de Claude: approche géomorphologique. In: Mélanges de l'Ecole Française de Rome, vol. 121, pp. 217-228.
Goiran, J.-P., Tronchère, H., Salomon, F., Carbonel, P., Djerbi, H., Ognard, C., 2010. Palaeoenvironmental reconstruction of the ancient harbors of Rome: Claudius and Trajan's marine harbors on the Tiber delta. Quat. Int. 216, 3-13.

Iadanza, C., Napolitani, F., 2006. Sediment transport time series in the Tiber River. Phys. Chem. Earth 31, 1212-1227.

Ingall, E., Jahnke, R., 1997. Influence of water-column anoxia on the elemental fractionation of carbon and phosphorus during sediment diagenesis. Mar. Geol. 139, 219-229.

Ingall, E.D., Bustin, R.M., Van Cappellen, P., 1993. Influence of water column anoxia on the burial and preservation of carbon and phosphorus in marine shales. Geochim. Cosmochim. Acta 57, 303-316.

Johnson, R.A., Wichern, D.W., 2007. Applied Multivariate Statistical Analysis, sixth ed. Prentice-Hall, Upper Saddle River.

Juvenal, 1974. Saturae, Collection des universités de France. les Belles lettres, Paris, France.

Keay, S., Millett, M., Paroli, L., Strutt, K., 2005. Portus: an Archaeological Survey of the Port of Imperial Rome. British School at Rome.

Keay, S.J., Paroli, L. (Eds.), 2011. Portus and its Hinterland: Recent Archaeological Research. Archaeological monographs of the British school at Rome. British School at Rome, London.

Le Gall, J., 1953. Le Tibre, fleuve de Rome dans l'Antiquité. Presses universitaires de France, Paris.

Le Roux, G., Veron, A., Morhange, C., 2003. Geochemical evidences of early anthropogenic activity in harbour sediments from Sidon. Archaeol. Hist. Leban. $18,115-119$.

Le Roux, G., Véron, A., Morhange, C., 2005. Lead pollution in the ancient harbours of Marseilles. Méditerranée, 31-35.

Lippi, M.M., Bellini, C., Trinci, C., Benvenuti, M., Pallecchi, P., Sagri, M., 2007. Pollen analysis of the ship site of Pisa San Rossore, Tuscany, Italy: the implications for catastrophic hydrological events and climatic change during the late Holocene. Veg. Hist. Archaeobot. 16, 453-465.

Lugli, G., Filibeck, G., 1935. Il porto di Roma imperiale e l'agro portuense. Officine dell'Istituto Italiano d'Arti Grafiche, Roma.

Marriner, N., Morhange, C., 2007. Geoscience of ancient Mediterranean harbours. Earth-Sci. Rev. 80, 137-194.

Marriner, N., Morhange, C., Goiran, J. p, 2010. Coastal and ancient harbour geoarchaeology. Geol. Today 26, $21-27$.

Mazzini, I., Faranda, C., Giardini, M., Giraudi, C., Sadori, L., 2011. Late Holocene palaeoenvironmental evolution of the Roman harbour of Portus, Italy. J. Paleolimnol. 46, 243-256.

Morhange, C., Marriner, N., 2009. Roman dredging in ancient Mediterranean harbours. Boll. Archeol. Online spec. IAAC, 23-32.

Noli, P., De Girolamo, P., Sammarco, P., 1996. Parametri meteomarini e dinamica costiera. In: Mare Del Lazio, Il (Ed.), Regione Lazio Assessorato opere e reti di servizi e mobilità. Università «La Sapienza» di Roma, pp. 285-331.

Pepe, C., Giardini, M., Giraudi, C., Masi, A., Mazzini, I., Sadori, L., 2013. Plant landscape and environmental changes recorded in marginal marine environments: the ancient Roman harbour of Portus (Rome, Italy). Quat. Int. 303, 73-81.

Reimer, P.J., Baillie, M.G.L., Bard, E., Bayliss, A., Beck, J.W., Blackwell, P.G., Ramsey, C.B., Buck, C.E., Burr, G.S., Edwards, R.L., Friedrich, M., Grootes, P.M., Guilderson, T.P., Hajdas, I., Heaton, T.J., Hogg, A.G., Hughen, K.A., Kaiser, K.F., Kromer, B., McCormac, F.G., Manning, S.W., Reimer, R.W., Richards, D.A., Southon, J.R., Talamo, S., Turney, C.S.M., Van der Plicht, J., Weyhenmeyer, C.E., 2009. IntCal09 and Marine09 radiocarbon age calibration curves, 050,000years cal BP. Radiocarbon 51, 1111-1150.

Sadori, L., Giardini, M., Giraudi, C., Mazzini, I., 2010. The plant landscape of the imperial harbour of Rome. J. Archaeol. Sci. 37, 3294-3305.

Salomon, F., Goiran, J.-P., Bravard, J.-P., Arnaud, P., Djerbi, H., Kay, S., Keay, S., in press. A harbour-canal at Portus: a geoarchaeological approach to the Canale Romano-Tiber delta, Italy. Water Hist.

Salomon, F., Goiran, J.P., Bravard, J.P., Millett, M., Strutt, K., Kay, S., Earl, G., Paroli, L., Keay, S., 2010. Delta du Tibre - Campagne de carottage 2009-Géoarchéologie des canaux de Portus: l'exemple du Canale Romano. In: Chroniques des Mélanges de l'Ecole Française de Rome, vol. 122, pp. 263-267.

Salomon, P., Delile, H., Goiran, J.-P., Bravard, J.-P., Keay, S., 2012. The Canale di Comunicazione Traverso in Portus: the Roman sea harbour under river influence (Tiber delta, Italy). Géomorphologie, 75-90.

Stuiver, M., Becker, B., 1986. High-precision decadal calibration of the radiocarbon time scale, AD 1950-2500 BC. Radiocarbon 28 (2B), 863-910.

Suétone, 1993. In: 4 éd.Vies Des Douzes Césars, Tibère - Caligula - Claude - Néron Des Universités de France T. 2. Les Belles Lettres, Paris.

Tacitus, 2010. Annales, Collection Des Universités de France. Les Belles lettres, Paris.

Véron, A., Goiran, J.P., Morhange, C., Marriner, N., Empereur, J.Y., 2006. Pollutant lead reveals the pre-Hellenistic occupation and ancient growth of Alexandria, Egypt. Geophys. Res. Lett. 33, 1-4.

Vizzini, S., Sarà, G., Mateo, M.A., Mazzola, A., 2003. $\delta^{13} \mathrm{C}$ and $\delta^{15} \mathrm{~N}$ variability in Posidonia oceanica associated with seasonality and plant fraction. Aquat. Bot. 76, 195-202. 